\title{
Toward a Multi-Causal Model of Successful Conflict Regulation through Territorial Self-Government: Lessons from South Tyrol
}

\section{Felix Schulte}

Institute of Political Science, Heidelberg University

felix.schulte@ipw.uni-heidelberg.de

\begin{abstract}
Territorial autonomies have been increasingly implemented as tools for the regulation of ethnic self-determination conflicts. Recent literature has primarily focused on the debate about the general conflict-solving potential of territorial self-government in multi-ethnic societies. However, autonomy consolidation is not an entirely endogenous process, but affected by various structural and actor-centered factors. Previous studies have so far given unsatisfactory answers as to the conditions under which reforms of autonomy succeed or fail in post-conflict situations. Building on Social Identity Theory, it is argued that ethnic recognition is the all-important condition for autonomy consolidation, which, however, presupposes specific, favorable framework conditions. A high scope of transferred competencies, weak horizontal inequalities, democratic-inclusive institutions, minority-friendly parties, and international engagement are identified as pivotal factors supporting the process of mutual recognition between ethnic groups. To test our theoretical assumptions, we create a multi-causal process model. We find evidence for the proposed mechanisms in a process-tracing case study on South Tyrols successful autonomy consolidation.
\end{abstract}

\section{Keywords}

Territorial autonomy, Self-determination, Ethnic conflict, Conflict regulation, South Tyrol

\section{Ein multikausales Modell erfolgreicher Konfliktregulierung durch Territorialautonomie - der Fall Südtirol}

\section{Zusammenfassung}

Mitunter stellen Autonomiereformen eine geeignete institutionelle Option dar, um ethnische Selbstbestimmungskonflikte in friedliche Bahnen zu lenken. Gleichwohl sind Territorialautonomien weder ein Allheilmittel noch von vornherein zum Scheitern verurteilt. Der Artikel argumentiert, dass die Konsolidierung eines Autonomiearrangements von einem Zusammenspiel günstiger struktureller und akteurzentrierter Faktoren abhängt, die eine gegenseitige Anerkennung zwischen Mehrheit und Minderheit als Grundvoraussetzung für ethnischen Frieden ermöglichen. Der Fall Südtirol macht deutlich, dass dem Grad an Selbstbestimmung, horizontalen Ungleichheiten, demokratisch-inklusiven Institutionen, minderheitenfreundlichen Parteien und internationaler Unterstützung eine entscheidende Rolle zukommt.

\section{Schlüsselwörter}

Territorialautonomie, Selbstbestimmung, Ethnische Konflikte, Konfliktregulierung, Südtirol

The author has declared that no competing interests exist. 


\section{Introduction}

Ethnic self-determination conflicts consistently remain a threat to international peace and security. Research draws attention to the importance of institutional reforms that peacefully manage conflicts on autonomy or secession. Institutions are regulatory frameworks which can impose constraints, define opportunity sets, and may create stimuli for political choices and, therefore, are often able to prevent violent re-escalation and restore ethnic peace. At the same time, post-conflict institutional engineering can have perverse effects, as it sometimes produces new tensions and grievances. However, both institutional successes and failures do not occur in a vacuum. Successful conflict regulation not only depends on the compatibility of the managing institution with the respective conflict situation, but also on future actor behavior within the institutional framework and on favorable context conditions. Territorial autonomy arrangements are at the heart of many resolutions to regulate ethnic self-determination conflicts as they provide self-government and minority protection while respecting state sovereignty and territorial integrity. Yet such a balance between transferred self-rule and shared-rule is often an unhappy compromise when ethnic groups are pursuing higher levels of self-determination and central governments are seeking to re-centralize powers. While territorial self-governance has led to ethnic peace in some cases, it has disastrously failed in others. How can this variance in outcomes be explained?

Ethnic self-determination conflicts are rooted in grievances on grievances and the non-recognition of cultural identity. Based on this theoretical argument, derived from Social Identity Theory (SIT), we argue that post-conflict autonomy arrangements succeed in peacefully regulating self-determination conflicts only if certain favorable conditions are in place to support a process of mutual recognition between the warring ethnic identity groups. Two key prerequisites are pivotal for autonomy consolidation, the first being that ethnic leaders need to accept the institutional framework. Ruling elites will opt for institutional reforms and engage in ongoing cooperation if they can expect to receive benefits and hold the public's support. A high degree of transferred competencies and attenuated grievances through weak intergroup inequalities provide necessary incentives for elites and ordinary group members to continuously support institutional reforms. Secondly, elites have to cooperate on a permanent basis. Institutions which encourage cooperative relationships at the central government level have the power to stabilize autonomous regions. A combination of democratic-inclusive institutions, minority-friendly parties, and international support builds a favorable and mutually reinforcing framework for rapprochement processes at the elite level. Success- ful elite cooperation then gives decisive impetus for societal rapprochement. This, in turn, builds the basis for mutual recognition and a reorganization of inter-group relationships.

We combine these theoretical considerations into a multi-causal model which explains consolidation outcome variance of territorial autonomy reforms as a specific, and often suitable, institution to manage ethnic self-determination conflicts. We contribute to the large literature on post-conflict institutional engineering in two important ways. First, we argue that autonomy consolidation is not simply a matter of institutional design or only explained by country-level variables, a main focus of the current literature. Our study uses a qualitative and case-oriented approach and combines both microand macro-level variables, a stark difference from the recent regression-based analyses. This provides a deeper and more comprehensive explanation for the puzzle outlined above. Second, unlike the rest of the ongoing literature, our analysis is not based on the assumption that autonomy success has a mono-causal explanation, but rather it takes multi-causality into account and focuses on the combination of different structural and actor-centered conditions. This approach has not yet been adequately or thoroughly addressed in any of the research on territorial autonomy thus far.

This article is organized into five different sections. The next section shortly reflects on the general debates in literature on territorial self-government as a conflict management tool. Section three introduces the success factors and develops the process model. In section four, we select all relevant cases of conflict-regulating autonomy and assess their consolidation outcomes. The South Tyrolean Autonomy Agreement proves to be a typical case that shows all relevant conditions and is suitable for a model test. In the fifth section, we conduct the process analysis and the final section summarizes the results and concludes with a discussion of policy implications, in addition to providing avenues for further research.

\section{Territorial Self-Government as a Conflict Regulation Tool}

Territorial self-governance is a geographically defined sub-state that has been granted special status in the course of a peace process, which cannot be dismissed unilaterally, and which contains exclusive legislative powers. A self-determination seeking group can manage both its own cultural and political affairs, but central powers remain under the control of the central state. Territorial self-governance provides ethnic groups official recognition of their cultural identity and security against discriminatory state practices. Central power structures lose importance which ensures a balance of 
power between the periphery and the center (Hartzell, Hoddie, and Rothchild 200I; Weller and Nobbs 20I2).

Many scholars see territorial autonomy solutions as a suitable institutional compromise between demands for self-determination and the concerns nation-states have for maintaining sovereignty and territorial integrity (Lapidoth 1997; Safran and Máiz 2000; Weller and Wolff 2005). Others argue that autonomy structures facilitate ongoing centrifugal activities and promote secession movements (Chapman and Roeder 2007; Anderson 20I4). Ethnic empowerment may institutionalize ethnic cleavages, deepening rather than ameliorating social identities. The implementation of self-government homogenizes on a 'second level' and excludes other groups as autonomous areas are normally home to their own minorities (Barter 2018). There may be a contagion effect at work when other ethnic leaders in the country are encouraged to challenge the state in the hope of gaining power (Hale 2000; Erk and Anderson 2013). Central governments can agree to autonomy reforms as part of a peace treaty, but once direct confrontations have ended, and international attention has faded, they could revoke transferred competencies. Consequently, these moves are then more likely to lead to the re-emergence of separatist violence.

In the recent past, some authors have tried to revive the deadlocked debate between proponents and critics of autonomy reforms by taking a more differentiated look at the autonomy-conflict nexus. Daftary and Cederman et al. conclude that autonomy regulations fail because they are implemented too late (Daftary 2008; Cederman et al. 2015). Siroky and Cuffe find that when groups have lost their autonomy status, the danger of secession is particularly high (Siroky and Cuffe 2015). Anderson and Costa find the balance of power to be influential (Anderson and Costa 2016). Schulte draws attention to the importance of the scope of transferred competencies (Schulte 20I8). Walsh recommends both national and international guarantees to overcome the innate instability of autonomy arrangements (Walsh 2018). A shift in research interest "away from the pros and cons of autonomy $[. .$.$] towards an effort to explain$ what factors influence the stability and longevity of autonomy solutions" (Åkermark 2013, I7) however, cannot (yet) be observed. Research so far has not provided a coherent theoretical framework under which conditions autonomy reforms work and under which circumstances they are likely to fail. It appears that conditions are seldom individually necessary or even sufficient for the success of post-conflict institutional reforms. This highlights the need for approaches that address multi-causal explanations and ones that take into account a combination of different favorable framework conditions that increase the chances of consolidation.

\section{Theoretical Model}

A basic assumption of Social Identity Theory (SIT) is that people strive for recognition of their identity and cannot be persuaded to abandon the satisfaction of this basic human need (Tajfel and Turner 1986; McKeown, Haji, and Ferguson 2016). They react with protective behavior when real experiences are not compatible with their self-concept. Since identity is also based on belonging to social groups, it is highly important which status the in-groups have in comparison to the outgroups. Recognition of social identity is given when out-groups recognize and accept that members of a group differ from them in terms of their culture, values, and norms, but do not devalue them based on the perceived cultural difference. Since language, religion, and traditions are dominant sources of identity, the need for recognition is particularly high for ethnic groups. Ultimately, the core of ethnic conflicts lies in non-recognition of ethnic identity (Gurr 1970; Horowitz 1985). From the perspective of those identity groups that do not have their own state, homogeneity and standardization in citizenship norms and territorial governance in modern nation-states are no less than a threat to their cultural identity. Many scholars have argued that the denial of such recognition demands is what leads to ethnic self-determination movements. Those can quickly escalate into bloody secession conflicts if suitable regulation mechanisms are missing or ignored. While any denial increases the risk of mobilization and secessionist sentiment, specific post-conflict institutions provide for empowerment or political inclusion and, eventually ethnic recognition. Current research confirms that this can, indeed, reduce the likelihood of violent group conflict (Cederman, Gleditsch, and Wucherpfennig 2017a; King and Samii 2017). The institutional logic of territorial self-government is based on limited self-determination and political empowerment, not on constant bargaining inherent to power-sharing arrangements. This significantly reduces the risk of mutual blockades and usurpation of political rule. Failed autonomies in Bangladesh's Chittagong Hill Tracts or India's Bodoland make it clear, however, that the theoretical performance potential does not necessarily unfold.

Since there are both successful and failed autonomies, the variance in outcomes cannot only be explained at the institutional level. Autonomy consolidation requires certain favorable framework conditions that support the difficult process of mutual recognition. Ordinary group members overcome their rivalry if, on one hand, they could benefit from the post-conflict order and, on the other hand, if they can be convinced that their willingness to remain part of the central state will not be disappointed and that their empowerment will remain present in the future. A credible commitment 
exists when elites enter into cooperation and send out critical signals for rapprochement. Elite cooperation is more likely to occur if opportunities, incentives, and pressure for bargaining processes are in place. At the same time, though, ethnic leaders rely on the support of the masses. This implies that both elite and group acceptance are necessarily interdependent processes. We argue that a high degree of transferred executive and legislative competencies and low group inequalities are crucial factors for acceptance, both for elites and ordinary group members.

\section{Acceptance}

The more policy areas regional institutions can decide upon, the greater the 'contribution' to a positive group identity and the more likely ethnic elites accept autonomy reforms. This suggests that autonomous regions with greater powers are more likely to consolidate and be able to prevent secessionist movements that undermine the ability to regulate conflicts. However, competencies that exist exclusively on paper do not contribute to a positive group identity or to a broad acceptance of institutional reforms (Schulte 2018). Only if group members can speak their own language and practice their religion and traditions can territorial self-governance fulfil its specific purpose. Ordinary group members are positive about institutional reforms when they expect them to improve their lives. This is the case when political empowerment and mutual recognition is not hindered by strong social or economic marginalization producing persistent grievances. Numerous studies confirm the correlation between group inequalities and internal conflict (Østby 2008; Stewart and Samman 2014) and highlight their role as a formidable tool of recruitment (Cederman, Weidman, and Gleditsch 20II). Therefore, it can be expected that strong horizontal inequalities between the majority and minority groups will hinder autonomy consolidation.

\section{Cooperation}

The general acceptance of elites and ordinary group members is followed by concrete cooperation efforts and elite pacts, only, though, if suitable cooperation opportunities are available to the actors in addition to sufficient incentives with certain pressure to adhere to agreements. We argue that democratic-inclusive institutions, minority-friendly parties, and international support are decisive factors for elite cooperation. As prominent scholars have previously pointed out, consociational democracies are able to protect minorities and mitigate ethnic tensions through inclusion and amicable agreements (Lijphart I99I; McGarry and O'Leary I993). Studies provide evidence that inclusive institutions such as parliamentarism or proportional electoral systems are capable of overcoming cultural cleavages between warring groups (King and Samii 20I7; Ansorg and Kurtenbach 2017; Cederman, Gleditsch, and Wucherpfennig 2017b). However, institutions are not simply exogenous instruments that exert pressure and provide incentives; they are also objects of manipulation by ethnic leaders and central governments because they can increase the chances of favorable outcomes. It is political parties that provide both the framework for political preferences of the elite and the guarantee that their investment in the autonomy institutions will pay off in the long run (Deschouwer, Deschouwer, and Luther 2004).

While moderately left-wing, conservative, or liberal parties often support multiculturalism for reasons of social justice or winning ethnic voters, far-right parties take anti-immigrant and anti-multicultural policy positions and promote power concentration. Such parties have a polarizing effect, negatively influence other parties and increase the likelihood of autonomy failure (Gherghina 2009; Westlake 2016). The participation of international actors in peace negotiations often implies long-term involvement as guarantors of post-conflict reforms. Organizations can change perceptions and shape preferences through incentives or pressure and they offer the possibility of exchanging information which could prevent dangerous security dilemmas. During the implementation phase, international actors can act as a strong verifier of compliance and pronouncements that one of the conflict parties has violated an agreement carry significant weight, making it difficult for the accused party to dismiss. However, these external interventions are limited in their mandate: ethnic groups need continuous support in order to transform their conflictual relationship into a peaceful one. If territorial autonomy becomes a part of the international community within the framework of international or regional networks, its autonomous status becomes definite. Member states can act as mediators in the event of tensions in addition to organizations unfolding a socialization effect that encourages bargaining and cooperation (Caporaso 1992). If these favorable conditions are present in an autonomy consolidation phase, cooperation between ethnic elites is likely. While elite cooperation efforts alone are not sufficient for autonomy consolidation, they give decisive impulses for ordinary group members and broad mutual recognition at the social level. The prerequisite, as previously mentioned, is the absence of feelings of relative deprivation. The theoretical assumptions are summarized in the following causal model: 
Figure 1: Causal Model

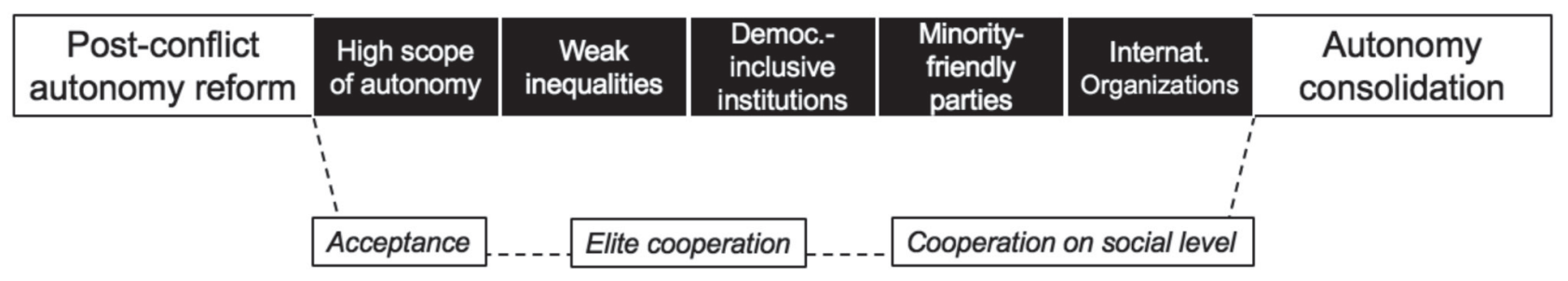

\section{Research Design}

To test the process model, we use mechanism-centered process tracing to find empirical evidence for the social mechanisms triggered by the conditions described above (George and Bennett 2005). In theory-testing analysis, it is advisable to study cases in which it is reasonable to assume that the particular mechanisms actually occur (Beach and Rohlfing 2015). The population for this case selection is all conflict-regulating autonomies that were implemented after 1945. In the first step, all relevant ethnic groups with autonomy rights were selected on the basis of the Ethnic Power Relations data set (Vogt et al. 2015). In the second step, the autonomy statutes implemented after 1945 that are still prevalent today were reviewed to determine whether the respective groups were granted territorial self-governance according to the definition criteria set above. In the third step, all cases of regional autonomy that were implemented as a result of an ethnic self-determination conflict were selected. This assessment is made using the Heidelberg approach to conflict research (Trinn and Wencker 2016; Heidelberg Institute for International Conflict Research 2018). This procedure leads to I9 territorial autonomies (Figure 2).

Figure 2: Conflict intensity in consolidation periods (1945-2017).

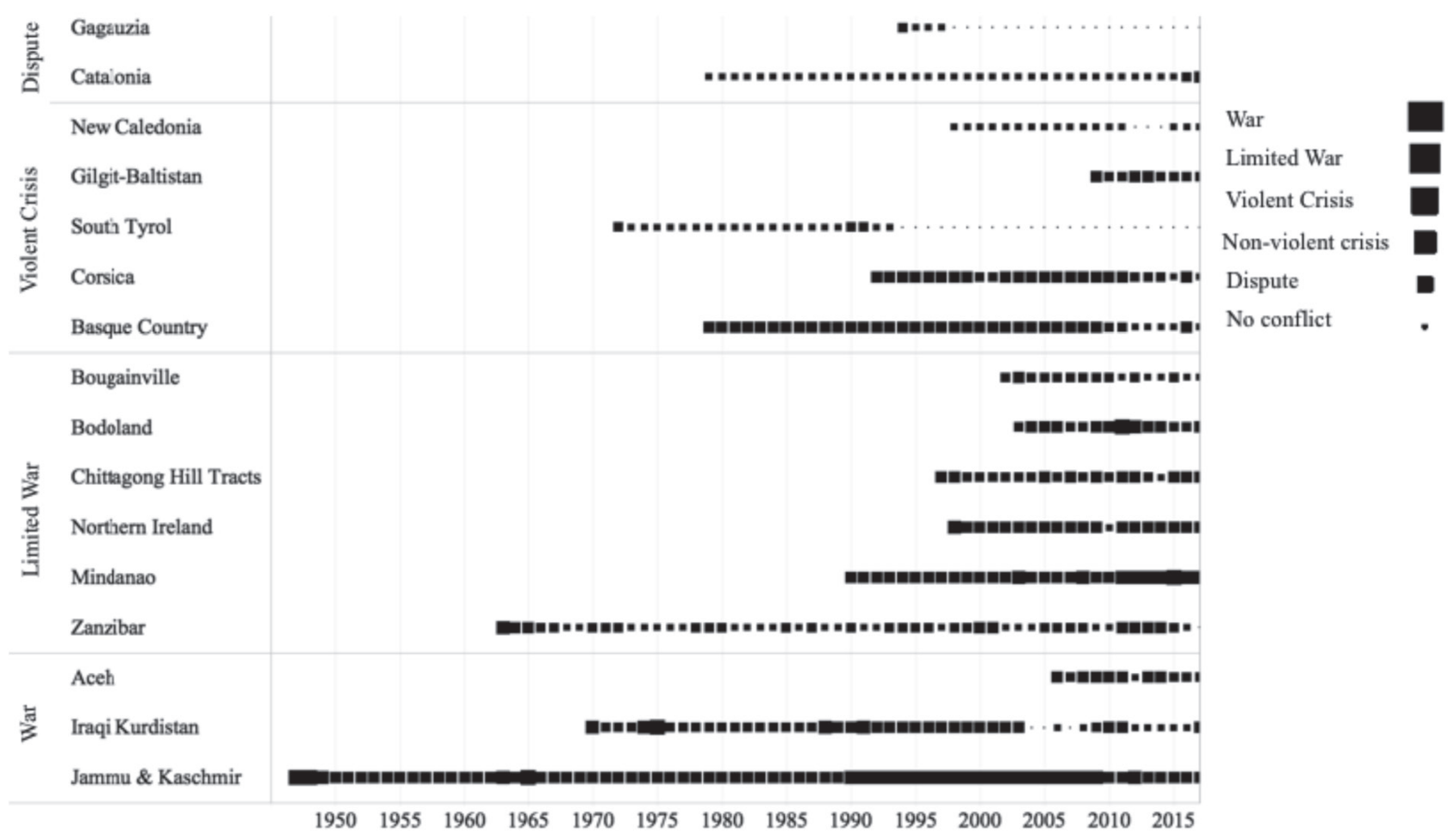

Note: The cases are sorted in ascending order by the highest previous conflict intensity. The cases Kuna Yala (Panama) and RAAN/RAAS (Nicaragua) cases were excluded for lack of data availability. 
A comparison of the consolidation phases shows that, in some cases, the conflict intensity gradually decreased, while in other cases the conflicts had either continued or even intensified. South Tyrol appears to be a typical case and is thus suitable for testing our theoretical model. Despite the preceding violent conflict in the region, the case shows a consistently peaceful consolidation phase, which is also comparatively long and contains all identified conditions. This autonomous region enjoys a relatively high degree of self-governance which has not been diminished and has led to a de facto empowerment of the South Tyroleans. There are no significant horizontal inequalities between Germans, Ladins, and Italians in terms of income, wealth, life expectancy, or access to health and social services (Atz, Haller, and Pallaver 2016; Pokriefke and Atz 2016; Provincial Statistics Institute South Tyrol 20I7). It should, therefore, be observed that these two conditions have initially led to acceptance at the political level. At the same time, favorable framework conditions for elite cooperation were in place. After the Second World War, Italy introduced parliamentarism and a proportional electoral system (Coppedge et al. 2018). Inter-ethnic commissions secured the political inclusion of the ethnic group in the peace process. The Democrazia Cristiana (DC), as the dominant party, largely represented center-left positions and largely upheld them until the end of the consolidation phase (Volkens et al. 20I7). At the regional level, the South Tyrolean People's Party (Südtiroler Volkspartei SVP) changed from a separatist party to a moderately conservative party. The peace process took place under the guidance of the international community. Already in the midst of the Paris Peace Conference in 1946, the basis for a statute of autonomy was negotiated between the Austrian government and Italy. After the conflict escalated, the I5th United Nations General Assembly called for peaceful conflict resolution by Resolutions 1497 (October 1960) and I66I (November I96I). The autonomous region was integrated into regional networks, for example the European Region Tyrol-South Tyrol-Trentino or the Committee of the Regions of the European Union.

\section{Successful Conflict Regulation through Territorial Self-Government: The Case of South Tyrol}

Despite the historical affinity of the German-speaking South Tyroleans with the Austrian kin-state, the territory was returned to Italy after the Second World War. The repressive assimilation attempts of the Italian central state provoked a strong antagonism between majority and minority. While the demands for a referendum on the reintegration to Austria remained unheard, the Allies insisted on protective provisions for the South Tyroleans. This prompted Italian Prime Minister De Gas- peri and Austrian Foreign Minister Gruber to reach an agreement to establish a regional authority. In February 1948, the central government decreed a first statute of autonomy, which, despite the bilateral agreement, did not entail real self-rule for the ethnic group as the government merged the German-speaking territory with the region of Trento into a single province, leaving decision-making powers in the hands of the Italian majority. When the repressive assimilation measures of the interwar period restarted, ethnic tensions escalated. After ever growing rallies, the first bombs of the South Tyrol Liberation Committee ('Befreiungsausschuss Südtirol', BAS) exploded at the end of the I950s, signaling years of terroristic violence, arbitrary arrests, curfews, and torture (Steininger 2004). During the course of the expanding conflict, the Austrian kin-state turned to the United Nations and, in October 1960, with Resolution I497 (XV), called on the parties "to resume negotiations with a view to finding a solution for all differences relating to the implementation of the Paris agreement" (United Nations 1960). In reaction to international pressures, Italian Minister of the Interior, Scelba, prevailed against internal party resistance and set up the I9 Commission, consisting of I2 Italians, six Germans, and one Ladin, to work out a solution to the South Tyrol conflict. The inclusive commission presented a series of proposals in April 1964, which were accepted by Foreign Ministers Saragat and Kreisky. Despite continued violent attacks, the parties agreed on a concrete catalogue of measures ('package') which marks the beginning of the consolidation phase.

\section{Acceptance of the Autonomy System by Political Elites}

After heated debates, the South Tyrolean People's Party (SVP), the mouthpiece of the German-speaking group, voted by a narrow majority at its party conference in November 1969 for the adoption of the 'package' deal (Steininger 2004, 132). The moderate package-supporters among Governor Magnago resisted the party's radical forces. The high degree of transferred competencies played an important role for the choices of the ethnic leaders. The argument of the advocates that "there will be no better offer" was ultimately much more powerful than the criticism of the opponents who could not make a realistic alternative proposal (Barlai, Griessler, and Lein 20I4). "What happens if we say no? No one was able to answer this question. I can tell you right now. The United Nations resolution enters into force (...). Then we will probably end up before the ICJ [International Court of Justice], as has already been said, without a package, because we said no (...). Now the rope is ripping. Bird eat or die! But when the bird eats, it lives, and otherwise it 
dies, that's the difference!" (Zeitgeschichte Informationssystem 1969). Magnago convinced his supporters with both the lack of realistic political alternatives and the possibility of the critics to exert influence in further negotiations and attained a symbolic handshake between the opponents (Solderer and Clementi 1999b). Despite the victory of the package proponents, a fundamental consensus for the autonomy solution grew among the ethnic elites, which agreed with the Italian government on a schedule ('operations calendar') for implementing the 'package' measures.

The high degree of autonomy that was gradually becoming a reality for the group members weakened the formerly dominant discourse of oppression. The continuous empowerment, in combination with the barely existing horizontal inequalities, led to a new cultural self-confidence. Although the package deal did not go far enough for many, the 'better than nothing' discourse of the elites was generally supported by the masses. The positive effects of far-reaching self-government pushed deprivation experiences into the background. It was found particularly positive that the now open public service offered well-paying jobs, the number of which increased from around I, Ooo to over 5,500 between 1970 and 1980 (Solderer and Clementi 1999a). They brought South Tyroleans closer to the central state administration, which had previously been reserved for Italians and been the origin of repressive assimilation measures. The wide-ranging competencies helped regain control over the identity-forming territory with its resources and symbols.

The autonomous province took over welfare, housing, and the preservation of monuments and quickly worked on enacting the first laws for the protection of 'their' flora and fauna. The articulation of suffering and the desire for reunification was soon replaced with a detailed discussion about the specific institutional design, policy-making processes, and constitutional guarantees (H. K. Peterlini 2OI3). The increased self-confidence was reflected in a decline in protests and in a high level of both political and economic activism. The perceptible decline in the feeling of deprivation paved the way for broad public and electoral support of the SVP under the leadership of charismatic Magnago. Its bureaucratic handling of the autonomy policy left little room for conflict-prone symbolism and took the self-determination movement's revolutionary spin. The BAS fighters, discredited by the political elite, were increasingly losing support. Starting in the mid-I970s, South Tyrol underwent a profound transformation that was brought about by the dynamic interplay of far-reaching selfgovernment, democratization, economic upswing, and a change in values. This proved to be surprisingly robust against the turbulence that occurred, like the language group survey in the 198I census, the rise of the neo-fas- cist Movimento Sociale Italiano (MSI), and the new wave of violent attacks in the I980s.

\section{Cooperation of Elites at State and International Level}

The final door opener for inter-ethnic cooperation at the political level was the democratization of the central state, the implementation of inclusive institutions by the Italian government, and a cultural opening in the course of the left-liberal shift in Italian politics. Between its foundation after the Second World War and the end of the millennium, the SVP changed from an irredentist separatist party into a moderate-conservative regional party (Ferrandi, Pallaver, and Leonardi 2007). The strong ethnic 'Volkstums'- ideology began to crumble after the first internal criticism in the 1960s, leading to deeper internal differentiation and a stronger focus on welfare policy. The ethnic cleavage, however, dictated the policy positions until the I990s: "the political objective is to secure and promote the German and Ladin ethnic groups and to consolidate them as a majority in their traditional homeland", as stated in the 1993 manifesto (Südtiroler Volkspartei 1993). Since the early I990s, a more pragmatic leadership took over the party administration and gradually expanded the ideological corset. Since 1998, the SVP has formally advocated a 'positive coexistence' with the Italian language group. That same year, in the national elections, a successful campaign for the Italian's suffrage occurred (Solderer and Clementi I999c). Although the party still defines itself in terms of ethnicity, the SVP can no longer be programmatically distinguished from other Christian Democratic parties, not least because the number of Italian voters is constantly growing (Hermannseder 2OI4).

The political-cultural opening of the SVP is a direct result of the party's strength and the decline in deprivation feelings. The South Tyroleans realized that they benefited from the special status and endowed the party with an absolute majority between 1948 and 2008. The elites, for their part, refrained from mobilizing again. The changed balance of power, as a result of the democratization of the central state and inclusive institutions, like a proportional electoral system or a regional powersharing executive, provided the basis for political rapprochement between the central government and the minority. Until the I96os, all regional parties shared the ideological positions of the SVP and agreed to the policy of ethnic separation. At the central state level, the era of center-left coalitions began in 1963 and heralded a political change. The center-left representatives took minority-friendly positions, particularly at the regional level, and ensured further rapprochement. In the mid-I970s, the New Left/Nuova Sinistra party, which was both pro- 
grammatically and organizationally inter-ethnically organized, took the final leap across the ethnic rubicon.

On the basis of this political change, cooperation efforts intensified within democratic-inclusive institutions and regional networks. One milestone was the aforementioned 19-Commission appointed by the Italian Council of Ministers under the leadership of Christian Democrat Scelba and chaired by Social Democrat Rossi. This inclusive forum offered suitable framework conditions to reach compromises because of the parties' similar policy positions. After 1972, the cooperation was successfully maintained in mixed commissions to develop implementing regulations. Former packagecritics were integrated in such institutions, which minimized the destructive potential of spoilers (O. Peterlini 1997). In the autonomous government, the SVP and the DC formed an enduring alliance that lasted from 1948 until I993. While inter-ethnic executive power-sharing is a fundamental principle of the autonomy statute, the continuity and crisis resistance of this cooperation is nonetheless worth mentioning. After 1993, the SVP forged coalitions with the parties of the center-left alliance Ulivo/Unione in the course of its programmatic opening and political transformation towards a moderate conservative party. The high willingness of the actors to cooperate in the difficult first phase of autonomy can be traced back to the similar party programs based on Catholicism and anti-Communism. The regional DC often acted as a mediating authority between the Roman DC and the SVP (Pallaver 20I4). Despite the majority voting system introduced between 1993 and 2005, South Tyroleans were always able to send representatives to both chambers of the Italian Parliament. Continuous political inclusion largely mitigated the deep mistrust towards the central state to such an extent that the SVP developed into an active political force in the Italian Parliament starting in 1990 and continuing onwards. In 200I, the party concluded an election agreement with the Italian center-left alliance, Ulivo. For the first time, SVP voters in the constituency of Bolzano supported an Italian candidate (Solderer and Clementi I999c, 5:70; Drüke 2013, 263).

Cooperation manifested and continued at the international level, particularly after the official settlement of the dispute in 1992 and the beginning of Europeanisation. Political integration in European networks offers further possibilities for not only communication networks and economic promotion, but also for gaining political significance and a form of 'external recognition'. European affairs became an important alternate option to the demand for reintegration. Within the Italian delegation to the European Union and within the European People's Party, the SVP cooperates successfully with other central state parties such as the Unione di Centro and the Nuovo Centrodestra and uses this mouthpiece to continuously 'present its own situation' (Provincial Administration South Tyrol 20II). The autonomy government is included in various regional networks, such as the Committee of the Regions of the European Union, the Alps Working Community (Arge Alp) with the regions of Italy, Austria, Germany and Switzerland, or a cooperation network of the regional parliaments of Tyrol, South Tyrol, Trentino and Vorarlberg.

\section{Rapprochement at Societal Level}

Despite the ethnic division policy of the SVP and group boundaries cemented by the declaration of language group affiliation, executive power-sharing and proportional representation, successful cooperation at the political level sent decisive signals for processes of rapprochement at the social level. The constant willingness to compromise and the moderate policy positions of political elites stopped the spiral of polarization and mistrust. The elites emphasized the advantages of the special status for South Tyrol instead of repeating the 'historical injustice' and group marginalization (H. K. Peterlini 2013). These impulses paved the way to move closer together both at the civil society and private sector level and, ultimately, to reorganize social relations from an 'against each other' attitude in the 1970s to a largely peaceful 'coexistence' in the I990s and, eventually, to an emerging 'togetherness' in the new millennium.

In the first decades of the consolidation phase, group membership had confessional character. With the student movement of 1968 , a slow and tenacious resistance against the cultural cleavage began. With Christian and peace-ethical arguments, students, intellectuals, and clergy tried to advance the rapprochement between South Tyroleans and Italians. However, disputes about the introduction of proportional representation in the public service, the allocation of social dwellings, and mandatory language tests forced the South Tyrolean society back into ethnic trench warfare: "All too often, the 'right' language group membership ranked before the qualification of the applicants, who might have been better doctors, technicians, or managers than their German-speaking colleagues, but were only Italians" (Solderer and Clementi I999a, 4:53).

After the establishment of territorial self-government, it took almost a decade for the tense group relations to ease. This is largely due to the coercive cooperation under the system of proportional representation. Prejudices were reduced through personal relationships, group boundaries were overcome and mutual trust was built up. Both sides recognized that both the special status as well as its concrete design as a consociational system offered advantages. A second important factor was entrepreneurs in the border region who, 
for mainly economic reasons, were hardly interested in growth-inhibiting ideologies. The South Tyrolean Business Association, for example, has openly expressed the multi-ethnic character of the region and thus promoted the rapprochement of groups in the labor market. Strong economic or social inequalities between majority and minority did not persist in the consolidation phase that would have prevented the rapprochement process between the groups.

The context conditions identified have allowed the autonomy reforms to turn the ethnic self-determination conflict into a state of peaceful co-existence. The political institutions continue to be functional and the autonomy arrangement is enjoying great social acceptance (Provincial Statistics Institute South Tyrol 2015b). By the mid-I980s, open confrontation and ethnic agitation was no longer socially acceptable. Whereas in I99I, $38 \%$ of Italians, Germans, and Ladins still perceived living together as problematic, the value dropped to II.I\% in 2004. Today only seven percent hold this opinion (Provincial Statistics Institute South Tyrol 2005, 2015a). These numbers indicate broad mutual recognition at mass level.

\section{Rapprochement at Societal Level}

Ethnic peace is not the result of an 'invisible hand', but rather of an emerging regime of accommodative institutions (Cederman and Vogt 2017). Post-conflict institutional reforms can transform ethnic self-determination conflicts into peaceful coexistence. Research has already developed an extensive 'menu of institutional engineering' and finds empirical evidence for peace-promoting effects of specific institutions (Ansorg and Kurtenbach 2017). Regional autonomy is not a relevant option for alleviating tensions between ethnic groups in all contexts. It is neither a panacea, nor does it have a 'terrible track record' (Snyder 2000, 327). Contrary to the arguments of critics, a majority of conflict-regulating autonomies have suffered neither recentralization nor secession. Where autonomy reforms have been implemented as part of a peace treaty to end ethnic conflict, most have succeeded in at least reducing violence to a manageable level. The evidence presented here suggests that the variation in outcomes is attributable, to a considerable extent, to favorable framework conditions initiating a three-step process of ethnic recognition; the first step being the general acceptance of ethnic leaders for institutional reforms; secondly, an expansive cooperation between ethnic elites at the political level and, finally, rapprochement and mutual recognition at the societal level. The case of South Tyrol has shown that only on the basis of a relatively high degree of autonomy, weak social and economic inequalities, and a factual empow- erment was the autonomy solution accepted among SVP elites. The fruitful combination of democracy, inclusive institutions, minority-friendly parties, and international pressure enabled continuous cooperation. These conditions were the catalysts for social rapprochement and re-organization of intergroup relationships.

This study has some important implications for researchers and policy-makers. The empirical results indicate that the search for success factors of post-conflict institutional reforms aimed at autonomy, decentralization, or power-sharing is much more beneficial than the search for a general performance potential of certain institutional arrangements. It is obviously not single context conditions that provide a sufficient explanation, but rather a combination of various favorable structural and actor-centered conditions. The positive news is that at least some key factors are relatively easy to shape. This applies, in particular, to the transfer of far-reaching autonomy rights in peace treaties, the creation of inclusive institutions in post-war orders, and support by international organizations to end ethnic self-determination conflicts.

\section{References}

Åkermark, Sia Spiiopoulou (2013), Internal Self-Determination and the Role of Territorial Autonomy as a Tool for the Resolution of Ethno-Political Disputes, in: International Journal on Minority and Group Rights, Vol. 20 (I), 5-25.

Anderson, Liam (2014), Ethnofederalism: The Worst Form of Institutional Arrangement...?, in: International Security, Vol. 39 (I), 165-204, Internet: https://doi. org/IO.II62/ISEC_a_OoI64.

Anderson, Liam/Carlos Costa (2016), Survival of the Fittest: Explaining the Success of Ethnic Autonomy Arrangements, in: Swiss Political Science Review, Vol. 22 (4), 516-44.

Ansorg, Nadine/Sabine Kurtenbach (ed.) (20I7), Institutional Reforms and Peacebuilding: Change, PathDependency and Societal Divisions in Post-War Communities, Londo/New York: Routledge, Taylor \& Francis Group.

Atz, Hermann/Max Haller/Günther Pallaver (ed.) (2016), Ethnische Differenzierung und soziale Schichtung in der Südtiroler Gesellschaft: Ergebnisse eines empirischen Forschungsprojekts, Baden-Baden: Nomos.

Barlai, Melani/Christina Griessler/Richard Lein (ed.) (20I4), Südtirol: Vergangenheit - Gegenwart - $\mathrm{Zu}$ kunft (Andrássy-Studien zur Europaforschung, Bd. 7), Baden-Baden: Nomos.

Barter, Shane Joshua (2018), Rethinking Territorial Autonomy, in: Regional Studies, Vol. 52 (2), 298-309, Internet: https://doi.org/IO.IO80/00343404.2017.I36665I. 
Beach, Derek/Ingo Rohlfing (2015), Integrating CrossCase Analyses and Process Tracing in Set-Theoretic Research: Strategies and Parameters of Debate, in: Sociological Methods \& Research, 47 (I), Internet: https:// doi.org/IO.II77/0049I24II56I3780.

Caporaso, James (1992), International Relations Theory and Multilateralism. The Search for Foundations, in: International Organization Vol. 46, 599-632.

Cederman, Lars-Erik/Kristian Skrede Gleditsch/Julian Wucherpfennig (20I7a), Predicting the Decline of Ethnic Civil War: Was Gurr Right and for the Right Reasons?, in: Journal of Peace Research, Vol. 54 (2), 262-74, https://doi.org/IO.II77/OO22343316684I9I.

- - - (2017b), The Diffusion of Inclusion: An OpenPolity Model of Ethnic Power Sharing, in: Comparative Political Studies, November, Internet: https:/doi. org/Io.II77/ooro4I40I7740602.

Cederman, Lars-Erik/Simon Hug/Andreas Schädel/Julian Wucherpfennig (2015), Territorial Autonomy in the Shadow of Conflict: Too Little, Too Late?, in: American Political Science Review, Vol. IO9 (02), 354-370, Internet: https://doi.org/IO.IOI7/Sooo30554I5000II8.

Cederman, Lars-Erik/Manuel Vogt (2017), Dynamics and Logics of Civil War, Journal of Conflict Resolution, Vol. 6I (9), I992-20I6, Internet: https://doi. org/IO.II77/OO220027I7721385.

Cederman, Lars-Erik/Nils B. Weidman/Kristian Skrede Gleditsch (20II), Horizontal Inequalities and Ethnonationalist Civil War - A Global Comparison, in: American Political Science Review, Vol. I95 (3), 478-94.

Chapman, Thomas/Philip G. Roeder (2007), Partition as a Solution to Wars of Nationalism: The Importance of Institutions, in: American Political Science Review, Vol. IOI (4), Internet: https://doi.org/IO.IOI7/ Sooo3055407070438.

Daftary, Farimah (2008), Territorial Autonomy as a Response to Violent Self-Determination Conflicts: 'Too Little, Too Late'?, in: SA Annual Convention 2008, San Francisco, 26-29 März 2008.

Deschouwer, Kris/Kris Deschouwer/Kurt Richard Luther (2004), Party Elites in Divided Societies: Political Parties in Consociational Democracy. London: Routledge.

Erk, J./L. M. Anderson (2OI3), The Paradox of Federalism: Does Self-Rule Accommodate Or Exacerbate Ethnic Divisions? London: Taylor \& Francis.

Ferrandi, Giuseppe/Günther Pallaver/Andrea Leonardi (2007), La regione Trentino-Alto Adige, Trento: $\mathrm{Mu}-$ seo storico in Trento.

George, Alexander L./Andrew Bennett (2005), Case Studies and Theory Development in the Social Sciences (BCSIA Studies in International Security), Cambridge, Mass: MIT Press.

Gherghina, Sergiu (2009), The Success of Extremist Parties in Central and Eastern European States and Its
Causes, in: U. Backes/T. Jaskulowski/A. Polese (ed.): Totalitarismus Und Transformation, Göttingen: Vandenhoeck and Ruprecht, I85-208, Internet: http:// eprints.gla.ac.uk/I38288/ (Accessed: I5.08.20I8).

Gurr, Ted Robert (1970): Why Men Rebel. Princeton: Princeton University Press.

Hale, Henry E. (2000), The Parade of Sovereignties: Testing Theories of Secession in the Soviet Setting, in: British Journal of Political Science, Vol. 30 (I), 3I-56.

Hartzell, Caroline/Matthew Hoddie/Donald Rothchild (200I), Stabilizing the Peace After Civil War: An Investigation of Some Key Variables, in: International Organization, Vol. 55 (I), I83-208, Internet:. https:// doi.org/IO.II62/002081801551450.

Heidelberg Institute for International Conflict Research (2018), Conflict Barometer 20I8, Internet: https:/hiik.de/ conflict-barometer/ (Accessed: 30.09.2018).

Hermannseder, Eveline (2014), Europas letzte grosse Volksparteien: Die Christlich-Soziale Union und die Südtiroler Volkspartei im Vergleich (Parteien Und Wahlen, Vol. 6), Baden-Baden: Nomos.

Horowitz, Donald L. (1985), Ethnic Groups in Conflict. Los Angeles: University of California Press.

King, Elisabeth/Cyrus Samii (20I7), Minorities and Mistrust: On the Adoption of Ethnic Recognition to Manage Conflict, in: Journal of Peace Research, August, 289-304, Internet: https://doi. org/IO.II77/0022343317707803.

Lapidoth, Ruth (1997), Autonomy. Flexible Solutions to Ethnic Conflicts, Washington, D.C.: United States Institute of Peace Press.

Lijphart, Arend (199I), Constitutional Choices for New Democracies, in: Journal of Democracy, Vol. 2 (I), 72-84, Internet: https://doi.org/IO.I353/jod.I99I.ooII.

McGarry, John/Brendan O'Leary (ed.) (I993), The Politics of Ethnic Conflict Regulation: Case Studies of Protracted Ethnic Conflicts, London/New York: Routledge.

McKeown, Shelley/Reeshma Haji/Neil Ferguson (ed.) (20I6), Understanding Peace and Conflict Through Social Identity Theory, Cham: Springer International Publishing, Internet: https://doi.org/Io.Ioo7/9783-319-29869-6.

Østby, Gudrun (2008), Polarization, Horizontal Inequalities and Violent Civil Conflict, in: Journal of Peace Research, Vol. 45 (2), I43-I62, Internet: https://doi. org/I0.1177/0022343307087169.

Pallaver, Günther (20I4), South Tyrol's Changing Political System: From Dissociative on the Road to Associative Conflict Resolution, in: Nationalities Papers, Vol. 42 (3), 376-98.

Peterlini, Hans Karl(20I3), Ioo Jahre Südtirol: Geschichte eines jungen Landes, Innsbruck: Haymon Verlag.

Peterlini, Oskar (1997), Autonomie und Minderheitenschutz in Trentino-Südtirol: Überblick über Ge- 
schichte, Recht und Politik (Ethnos, Vol. 48), Vienna: Braumüller.

Pokriefke, Eike/Hermann Atz (2016), Ethnische Differenzierung Und Soziale Ungleichheit in Der Südtiroler Gesellschaft, in: Staubmann, Helmut (2016): Soziologie in Österreich. Internationale Verflechtungen, Innsbruck University Press, Innsbruck, 438-46I, Internet: https://doi.org/10.15203/3122-56-7.

Provincial Administration South Tyrol (2OII), Alle News $\mid$ Bereich | Landesverwaltung | Autonome Provinz Bozen - Südtirol. 20 Jahre Europa-Angelegenheiten: 'Direkter Draht Zur EU', Internet: http://www.provinz. bz.it/ (Accessed: 03.02.2018).

Provincial Statistics Institute South Tyrol (2005), Südtiroler Sprachbarometer. Barometro Linguistico Dell'Alto Adige. Sprachgebrauch Und Sprachidentität in Südtirol. Bozen: ASTAT.

- - (2015a), Südtiroler Sprachbarometer. Barometro Linguistico Dell'Alto Adige. Sprachgebrauch Und Sprachidentität in Südtirol, Bozen: ASTAT.

- - - (2015b), Zufriedenheit der Bürger mit den öffentlichen Diensten, Nr. 5o', Bozen: ASTAT.

- - (2017), Datenbanken Und Gemeindedatenblatt, Internet: http://astat.provinz.bz.it/de/datenbankengemeindedatenblatt.asp (Accessed: 15.05.2018).

Safran, William/Rámon Máiz (2000), Identity and Territorial Autonomy in Plural Societies. London: Routledge.

Schulte, Felix (2018), The More, The Better? Assessing the Scope of Regional Autonomy as a Key Condition for Ethnic Conflict Regulation, in: International Journal on Minority and Group Rights, Vol. 25 (I), 84-III, Internet: https://doi.org/IO.II63/15718115-02511084.

Siroky, D. S./J. Cuffe (2015), Lost Autonomy, Nationalism and Separatism, in: Comparative Political Studies, Vol. 48 (I), 3-34, Internet: https://doi. org/IO.II77/OoIO4I4OI35I6927.

Snyder, Jack L. (2000), From Voting to Violence: Democratization and Nationalist Conflict. The Norton Series in World Politics, New York, NY: Norton.

Solderer, Gottfried/Siglinde Clementi (ed.) (1999a), Das 20. Jahrhundert in Südtirol. Autonomie Und Aufbruch, Vol. 4, Bozen: Edition Rætia.

- - (ed.) (1999b), Das 20. Jahrhundert in Südtirol: Totaler Krieg und schwerer Neubeginn, Bozen: Edition Rætia.

- - (ed.) (1999c), Das 20. Jahrhundert in Südtirol: Zwischen Europa und Provinz, Vol. 5, Bozen: Edition Rætia.

Steininger, Rolf (2004), South Tyrol: A Minority Conflict of the Twentieth Century, 2. print, New Brunswick, NJ: Transaction Publishers.

Stewart, Frances/Emma Samman (2014), Inequality and Development: An Overview, in: Bruce Currie-Alder/ Ravi Kanbur/David M. Malone/Rohinton Medhora (ed.), International Development: Ideas, Experience and Prospects, Oxford: Oxford University Press, 98II5.

Südtiroler Volkspartei (1993), Das neue Programm der Südtiroler Volkspartei beschlossen von der Landesversammlung am 8. Mai 1993, Meran: SVP, Internet: www.svp.eu (Accessed: 18.04.2018).

Tajfel, Henri/ John C. Turner (1986). The social identity theory of intergroup behavior, in: Stephen Worchel \& William G. Austin (Eds.), Psychology of intergroup relations, Chicago, Nelson-Hall, 7-24.

Trinn, Christoph/Thomas Wencker (2016), Introducing the Heidelberg Approach to Conflict Research, in: European Political Science, December, Internet: https:// doi.org/I0.1057/s41304-016-0093-4.

United Nations (1960), Resolutions Adopted on the Reports of the Special Political Committee (I497, XV), Internet: http://www.un.org/documents/ga/res/15/ aresi5.htm (Accessed: 10.02.2018)

Vogt, M./N.-C. Bormann/S. Ruegger/L.-E. Cederman/P. Hunziker/L. Girardin (2015), Integrating Data on Ethnicity, Geography, and Conflict: The Ethnic Power Relations Data Set Family, in: Journal of Conflict Resolution, Vol.o 59 (7), 1327-42, Internet: https://doi. org/IO.II77/0022002715591215.

Walsh, Dawn (2018), Territorial Self-Government as a Conflict Management Tool. Cham: Springer International Publishing, Internet: https://doi. org/I0.1007/978-3-319-77234-9.

Weller, M./Katherine Nobbs (2OI2), Asymmetric Autonomy and the Settlement of Ethnic Conflicts: National and Ethnic Conflict in the 2 Ist Century. Philadelphia, Pa./Oxford: University of Pennsylvania Press.

Weller, M./S. Wolff (2005), Autonomy, Self Governance and Conflict Resolution: Innovative Approaches to Institutional Design in Divided Societies, London: Taylor \& Francis.

Westlake, Daniel (2016), Multiculturalism, Political Parties, and the Conflicting Pressures of Ethnic Minorities and Far-Right Parties, in: Party Politics, November, Internet: https://doi.org/IO.I177/135406881667888I.

Zeitgeschichte Informationssystem (1969), 22./23.II.1969: Auszug der 18-Stunden-Debatte der SVP-Landesversammlung in Meran, Internet: https://www.uibk. ac.at/zeitgeschichte/zis/library/1969II22.html (Accessed: OI.04.2018).

\section{Author}

Felix Schulte is lecturer at the Institute of Political Science at Heidelberg University. His research agenda is situated at the nexus of comparative politics and peace research and focuses on minorities, ethnic conflicts and post-conflict institutional engineering. 
